\title{
Assessment of Inclusive Historical Public Spaces in achieving preservation of such areas in Malang, Indonesia
}

\author{
Case study: Public spaces developed during the Dutch Colonial \\ period
}

\author{
A.Tutut Subadyo ${ }^{1}$, Pindo Tutuko ${ }^{1 *}$, Septi Dwi Cahyani ${ }^{1}$ \\ 1 Department of Architecture, University of Merdeka Malang \\ *Corresponding Author, Email: pindotutuko@unmer.ac.id
}

Received: Jan 31, 2018; Accepted: March 27, 2018

Keywords: Assessment; Inclusive historical public spaces; Preservation

\begin{abstract}
Inclusive public spaces, a sort of "urban lungs" and "social binders", are a representation of responsive, democratic and meaningful space within the context of urban development. In the city of Malang, inclusive public spaces have undergone significant changes, and such changes may lead to a kind of degradation of the historical aspect which can in turn lead to a decline in the overall real condition of an area (spatial, sociological and ecological). Therefore, an assessment of historic spaces used as inclusive public space needs to be done in order to conserve their value to the community. This study aimed to identify the development of, existence of, physical characteristics of, and functions of these Inclusive Historical Public Spaces (IHPS); and also to analyse the integrity of the space values related to people's preferences and needs with respect to these spaces. This research used survey data collection techniques. Analysis and assessment of the space integrity was based on the quality and significance of space consisting of historical, aesthetic, and functional value. The study found that an inclusive historical space is affected significantly by the access to streets, which have different physical characteristics and functions in the four regions in Malang. To realize conservation of IHPS in Malang, which represent the history and image of an overall region, further support is needed through government policy in urban development management, as well as consideration as to the needs and aspirations of the public.
\end{abstract}

\section{INTRODUCTION}

Open public space is an important element as a counterweight in both urban and rural space (Subadyo, A Tutut \& Poerwoningsih, 2017). The existence of such public space gives evidence of changing human needs over time (Kostof \& Castillo, 1992). According to research (Nasution \& Zahrah, 2012), many open public spaces are found to be managed by the private sector. However, privatization often has negative impacts, such as limiting access, 
increasing consumerism, social inequalities, declining democratic expression and social interaction. Thus, interest should be paid to the development of inclusive space which can be accessed and utilized easily by everyone and which supports human activities (Carr et al., 1992). In order to achieve this ideal of a democratic and inclusive public space, space often with historical significance, some assessment is required.

Malang is a city in Indonesia which still has many traces of historic urban space, including open public space dating from the era of Dutch colonization (Ridjal et al., 2016; Sunaryo et al., 2013). Historic public space can project a certain aesthetic value for the entire region as well as create a sense of inclusiveness for the city (Mehta, 2014). However, many inclusive public spaces within the city have changed over time as the city has grown (Harun, Mansor, \& Said, 2015). In Malang, since the beginning of the postindependence era, this situation has led to a decline in the the space's historical value, the quality of spatial-ecology, aesthetics, and also the human sociological function.

An understanding of the importance of historical public places to the townspeople needs to be considered, especially in areas which have undergone continuous change and disassembly, which has caused the loss of historical character and uniqueness. To achieve a sustainable urban form, the existence of such spaces needs to be maintained to preserve the overall vitality of the city (Bandarin \& van Oers, 2015). The value of inclusive public spaces is also closely related to the quality of a space's design (physical form/ aesthetic). The aesthetic element has a comprehensive impression that emerges from the community perception (Carmona, 2015). The aesthetic has relation to the way the area is seen by the public (giving a sense of safety and comfort) (Alamoush et al., 2017). This is not only considered to be environmental (social engagement and community empowerment) assets but also monumental (the sensorial experience of the "townscape") assets. The morphological work above shows the spontaneous, balanced development of characters, and natural resources within each of these areas (Romice et al., 2017; Tutuko \& Shen, 2016).

Nowadays, citizens of various ages, though in particular the elderly, interact within the context of the public space. Access to such space needs to be taken into consideration to ensure that such people can use the space (Srichuae, Nitivattananon, \& Perera, 2016; Yoshii, 2016). Elements and facilities contributing to such access are key to the space's utilization. An important aspect of urban development planning is the ensuring of such accessibility as an aspect of enabling the mobility of people in a developing city. The power of globalization towards local identity and regional diversity affects urban shape shifts and the existence of public space (Kaymaz, 2013). This new insight will strengthen the conservation effort, the regulatory support from stakeholders, and also the awareness of planners and architects (AbdelRahman, 2016).

In general, support for historical space is required to prevent the extinction of human civilization itself. The function of such space requires an attention to the aesthetic aspect (as a level of visual comfort satisfaction) and also to the fulfillment of the needs of human activity. Furthermore, the local government should have comprehensive guidance in managing the existing Inclusive Historical Public Spaces (IHPS). The historical space needs to avoid being a mere centralization point of sociometric activity, which may simply relate it to the problems of an inner city (Hardoy \& Satterthwaite, 2014). 
The objective focus of this research is based on the three main issues (i.e. history, aesthetic and function), which need assessment as well as regard as focal points in preserving and utilizing IHPS in order to maintain sustainability within urban development in Malang. The utilization of IHPS in accordance with the preservation principle will support the vitality of the maintenance area.

This paper discusses the assessment of IHPS, which will be helpful to supporting ideas on the preservation of such urban areas. It is compiled in three main sections. The first section presents the development of IHPS in existence in Malang, which has significant implications on characteristics of public spaces. Secondly, it assesses the public space integrity based on the quality and significance of the IHPS. Then, the last section contains the assessment analysis based on human preference.

\section{METHODOLOGY}

This research used a descriptive qualitative method with a survey included (non-experimental). The investigation of the existence of IHPS in Malang, an assessment of them, as well as an analysis of their characteristics as space, provides a starting point for determining the concept and direction for the preservation of such historic space. The existence of IHPS may be traced back through old maps and literature in relation to the periodization in which a particular space was able to survive and are studied further based on the type/character and the forming function. Moreover, assessment and analysis of the public space integrity is based on the quality and significance of the IHPS which consists of historical, aesthetic and functional value (Arifin, Arifin, \& Suryadarma, 2002) where the variables, indicators and parameters are shown in the following tables.

Table 1. Variables, Indicators and Parameters Based on the Historical Value

\begin{tabular}{|l|l|c|c|c|c|c|c|}
\hline \multicolumn{1}{|c}{ Variable } & \multicolumn{1}{|c|}{ Indicator } & High & V & Moderate & V & Low & V \\
\cline { 2 - 8 } $\begin{array}{l}\text { Chronological } \\
\text { Value }\end{array}$ & $\begin{array}{l}\text { The level of } \\
\text { regional age }\end{array}$ & $>100$ years & 3 & $\begin{array}{c}50-100 \\
\text { years }\end{array}$ & 2 & $\begin{array}{c}<50 \\
\text { years }\end{array}$ & 1 \\
\hline Historical Facts & $\begin{array}{l}\text { The number } \\
\text { of historical } \\
\text { facts }\end{array}$ & $>5$ & 3 & $2-5$ & 2 & $<2$ & 1 \\
\hline Uniqueness & $\begin{array}{l}\text { The number } \\
\text { of similar } \\
\text { objects }\end{array}$ & None & 3 & $\begin{array}{c}1-10 \\
\text { similar } \\
\text { object }\end{array}$ & 2 & $\begin{array}{c}>10 \\
\text { similar } \\
\text { object }\end{array}$ & 1 \\
\hline Historical Events & $\begin{array}{l}\text { The level of } \\
\text { historical } \\
\text { events that } \\
\text { occurred }\end{array}$ & International & 3 & National & 2 & Regional & 1 \\
\hline Wholeness & $\begin{array}{l}\text { The level of } \\
\text { wholeness }\end{array}$ & $80-100 \%$ & 3 & $50-79 \%$ & 2 & $10-49 \%$ & 1 \\
\hline
\end{tabular}

High historical value, if the total value $=13-15$; Moderate historical value, if the total value $=$ 9-12; Low historical value, if the total value $=5-8$.

Source: (Australia ICOMOS Incorporated, 2000, 2013; Catanese \& Snyder, 1988; Helly \& Budiarti, 2005).

Table 2. Variables, Indicators and Parameters Based on the Aesthetic Value

\begin{tabular}{|l|l|l|c|c|c|c|c|}
\hline \multirow{2}{*}{ Variable } & \multirow{2}{*}{ Indicator } & \multicolumn{7}{|c|}{ Parameter } \\
\cline { 3 - 8 } & & High & V & Moderate & V & Low & V \\
\hline $\begin{array}{l}\text { Representa- } \\
\text { tion of a } \\
\text { Particular Style }\end{array}$ & $\begin{array}{l}\text { Regional image } \\
\text { representation } \\
\text { (Traditional/ }\end{array}$ & $\begin{array}{l}\text { Very } \\
\text { represent- } \\
\text { ative }\end{array}$ & 3 & $\begin{array}{c}\text { Quite } \\
\text { represent- } \\
\text { ative }\end{array}$ & 2 & $\begin{array}{c}\text { Less } \\
\text { represent- } \\
\text { ative }\end{array}$ & 1 \\
\hline
\end{tabular}




\begin{tabular}{|c|c|c|c|c|c|c|c|}
\hline \multirow{2}{*}{ Variable } & \multirow{2}{*}{ Indicator } & \multicolumn{6}{|c|}{ Parameter } \\
\hline & & High & $\mathrm{V}$ & Moderate & $\mathrm{V}$ & Low & $\mathrm{V}$ \\
\hline $\begin{array}{l}\text { (Contextual and } \\
\text { Homogeneous) }\end{array}$ & $\begin{array}{l}\text { Colonial/ } \\
\text { Chinatown) }\end{array}$ & & & & & & \\
\hline Proportion & $\begin{array}{l}\text { Proportion of } \\
\text { Width to } \\
\text { Height }\end{array}$ & $\begin{array}{c}\mathrm{W} / \mathrm{H}> \\
1,5\end{array}$ & 3 & $\begin{array}{l}\mathrm{W} / \mathrm{H}= \\
1-1,5\end{array}$ & 2 & $\begin{array}{c}\mathrm{W} / \mathrm{H}> \\
1,5\end{array}$ & 1 \\
\hline Rhythm & $\begin{array}{l}\text { Continuity of } \\
\text { street wall }\end{array}$ & Continues & 3 & $\begin{array}{l}\text { Some are } \\
\text { disconnec } \\
\text {-ted }\end{array}$ & 2 & $\begin{array}{l}\text { Disconne- } \\
\text { cted }\end{array}$ & 1 \\
\hline Scale & $\begin{array}{l}\text { Human scale } \\
\text { (comparison) }\end{array}$ & $\begin{array}{l}\text { Monume- } \\
\text { ntal scale }\end{array}$ & 3 & $\begin{array}{l}\text { Human } \\
\text { scale }\end{array}$ & 2 & $\begin{array}{l}\text { Intimate } \\
\text { Scale }\end{array}$ & 1 \\
\hline
\end{tabular}

High historical value, if the total value $=10-12 ;$ Moderate historical value, if the total value $=$ 7-9; Low historical value, if the total value $=4-6$.

Source: (Jacobs, 1993; Helly \& Budiarti, 2005)

Table 3. Variables, Indicators and Parameters Based on the Functional Value

\begin{tabular}{|c|l|c|c|c|c|c|c|}
\hline \multirow{2}{*}{ Variable } & \multicolumn{1}{|c|}{ Indicator } & High & $\mathrm{V}$ & Moderate & $\mathrm{V}$ & Low & $\mathrm{V}$ \\
\cline { 3 - 8 } Amenities & $\begin{array}{l}\text { Separation } \\
\text { between } \\
\text { pedestrians } \\
\text { and vehicles }\end{array}$ & Clear & 3 & Unclear & 2 & None & 1 \\
\hline Accessibility & $\begin{array}{l}\text { Link system/ } \\
\text { "Oldtown" } \\
\text { linkage }\end{array}$ & $\begin{array}{c}\text { Direct } \\
\text { linkage } \\
\text { system }\end{array}$ & 3 & $\begin{array}{l}\text { Indirect } \\
\text { linkage } \\
\text { system }\end{array}$ & 2 & $\begin{array}{c}\text { Unrelated } \\
\text { linkage } \\
\text { system }\end{array}$ & 1 \\
\hline $\begin{array}{l}\text { Economic } \\
\text { Usefulness }\end{array}$ & $\begin{array}{l}\text { Number of } \\
\text { commercial } \\
\text { front stores }\end{array}$ & $\begin{array}{c}\text { Found }> \\
50 \%\end{array}$ & 3 & $\begin{array}{c}\text { Found } \\
10-50 \%\end{array}$ & 2 & $\begin{array}{c}\text { Found } \\
10 \%\end{array}$ & 1 \\
\hline Social Needs & Activity & $\begin{array}{c}\text { Found > } \\
\text { activities }\end{array}$ & 3 & $\begin{array}{c}\text { Found } \\
2-3 \\
\text { activities }\end{array}$ & 2 & $\begin{array}{c}\text { Found only } \\
1 \text { activity }\end{array}$ & 1 \\
\hline
\end{tabular}

High historical value, if the total value $=10-12 ;$ Moderate historical value, if the total value $=$ 7-9; Low historical value, if the total value $=4-6$.

Source: Carmona et al. (2010)

The value rating was processed by a peer group of the Centre of Environmental and Landscape Study, Department of Architecture, University of Merdeka Malang through expert judgement. This method is used to determine the value of each criterion where the total value of its criteria generates the value of space integrity (Equation 1) (Arifin, Arifin, \& Suryadarma, 2002). The overall results are classified into three levels, i.e., high integrity space (rating of 31-39), moderate integrity space (rating of 2230 ), and low integrity space (rating of 13-21).

$$
\mathbf{I}=\sum \mathbf{H}+\sum \mathbf{A}+\sum \mathbf{F}
$$

Equation 1. Formula of Space Integrity. Source: Arifin, Arifin, and Suryadarma (2002)

Description:

I = Space Integrity Value;

$\mathrm{H}=$ Historical Value;

$\mathrm{A}=$ Aesthetic Value;

$\mathrm{F}=$ Functional Value.

Subsequently, a community preference analysis was conducted to examine the needs of the community in the use of public space as an inclusive historical space. The respondent data came from selected zones which were based on the Malang bouwplan development underlying the centre of Malang from the Dutch colonial era (Celaket - Kayutangan - Alun-alun, Ijen - Gajayana Stadium, Tugu - Rampal, and Sukun - Kasin). The data processing used purposive sampling method (Ritchie et al., 2013) in which 30 respondents both in the visitors and residents category were involved in each of those four 
zones. The respondents of Celaket-Kayutangan-Alun-alun zone consisted of the town square (Alun-alun) visitors $(\mathrm{n}=15)$ and its area residents $(\mathrm{n}=15)$. In Ijen-Gajayana Stadium, the respondents were composed of the stadium visitors $(\mathrm{n}=15)$ and the cultural conservation building owners/residents $(\mathrm{n}=$ 15). In Tugu-Rampal, the sample respondents were taken from Tugu and Rampal park visitors $(n=15)$ and its area residents $(n=15)$. The respondents of the Sukun-Kasin zone consisted of the Sukun Cemetery and Soepraoen Army Hospital visitors $(n=15)$ and the residents around Raya Dieng, Langsep and Sodanco Supriadi streets $(\mathrm{n}=15)$. This sampling method was based on the users' first determination. The sample group was drawn from $20 \%$ of the total number of average weekly visitors to each particular area.

Table 4. Variable, Sub Variables and Operational Variables

\begin{tabular}{|c|c|c|}
\hline Variable & Sub Variable & Operational Variable \\
\hline \multirow{4}{*}{$\begin{array}{l}\text { Amenities and } \\
\text { Images }\end{array}$} & \multirow{2}{*}{ Image } & Maintaining historic physical characteristics \\
\hline & & The availability of pedestrian ways \\
\hline & \multirow{2}{*}{$\begin{array}{l}\text { Safety and } \\
\text { amenities }\end{array}$} & $\begin{array}{l}\text { The availability of street furniture, such as seating, } \\
\text { trash bins, street lighting and others }\end{array}$ \\
\hline & & The availability of vegetation barriers \\
\hline \multirow{4}{*}{$\begin{array}{l}\text { Access and } \\
\text { Linkage }\end{array}$} & Access & $\begin{array}{l}\text { The availability of municipal transport and its } \\
\text { improvements }\end{array}$ \\
\hline & Linkage & The availability of pedestrian way linkages \\
\hline & \multirow{2}{*}{ Transit } & The availability of halte/ transit shelters \\
\hline & & The availability of car parks \\
\hline \multirow{4}{*}{$\begin{array}{l}\text { Economic } \\
\text { Usefulness }\end{array}$} & Street market & Structuring and coordinating of street traders \\
\hline & \multirow{2}{*}{ Investor } & Involvement of local communities and investors \\
\hline & & Investor's right to choose the company types \\
\hline & Utilization & The utilization of IHPS for commercial purposes \\
\hline \multirow{4}{*}{ Social Needs } & Event & Enhancement of type and frequency of activities \\
\hline & Evening Use & Extra hours of activity (up to night events) \\
\hline & \multirow{2}{*}{ Facility } & Provision of facilities for various ages \\
\hline & & Social integration of support facilities \\
\hline
\end{tabular}

Source: (Carmona et al., 2010; Helly \& Budiarti, 2005)

All respondents $(\mathrm{n}=120)$ gave answers to the questionnaire of operational variables related to public space utilization (Table 4.). The questionnaire contained closed questions with a choice of quantitative answers related to the importance level of IHPS and measured using a Likert scale. The results of the answers were then analysed using (1) the validity and reliability test and (2) further analysis. A validity test was used to determine the validity level of question variables in the questionnaire. That is, it examined the corrected item value for each variable and compared it with the R table (from SPSS 15 software support) by using the scale analysis. Beyond this, Cronbach's Alpha method was applied to the reliability test. The calculation of its method is based on the median intercorrelation among the question items in the questionnaire where reliability is shown when the alpha value is more than 0.6. Finally, the respondents' answers were analysed by using the descriptive analysis method of Chi-Square.

\section{THE DEVELOPMENT OF INCLUSIVE HISTORICAL PUBLIC SPACES IN MALANG}

Malang, as the second largest city in East Java, grew rapidly after being taken over by the Dutch colonial government. That rapid development was marked by the expansion of transportation modes and intercity lanes to the north of Malang (Malang-Pasuruan-Surabaya) in the 1870s (Baskoro, 2017; 
Handinoto, 1996), and also urban planning from 1917 in eight phases (Figure 1(a)) (Basundoro, 2015; Santoso, Suryasari, \& Antariksa, 2013; Handinoto, 1996).

The first milestone of Malang's urban development (phase I/ bouwplan I) was completed on May 18, 1917 in the form of a housing establishment for Europeans (Oranjebuurt) in Celaket (Jaksa Agung Suprapto street) and Rampal (Panglima Sudirman, Pattimura and Urip Sumoharjo streets). Later, on 26 April 1920 was initiated phase II of the city expansion (bouwplan II) with a focus on the development of a regional administrative centre (Gouverneur General Buurt) Malang. In the centre, there was a landmark round square (JP Coen Plein) which became a point of confluence and public space distribution (Tugu, Mojopahit, Suropati, Kertanegara, Kahuripan and Sultan Agung streets). Since then, the city was developed and built with a concentric urban spatial structure, like small towns of Europe in the 18th century, where the round square became the city centre. Formerly, all roads in the area used names from the Netherlands.

In bouwplan III, the Sukun area was chosen as the European cemetery complex due to its territory being the main access connecting Malang and Blitar (west side of Malang). Moreover, in bouwplan IV, middle and lower housing development was placed on the area between Brantas River, with access to the town and Samaan public cemetery. In 1924, bouwplan V the housing for affluent residents was built (Ijen street) and the sports area (Gajayana Stadium) surrounded by Semeru, Tangkuban Perahu and Kawi streets. At that time, Dutch and other European families exclusively enjoyed Ijen Boulevard and its surrounding areas, while the indigenous people had to settle for living in the suburbs with their inadequate facilities. In phase VI of urban development, Malang expanded to the old town of Mergosono Eilandenbuurt. In bouwplan VII, the city developed an upper class residential area in the west of the city. Lastly, the development and supply of industrial estates was allocated in the southern part of Malang as the final stage of urban development prior to independence (bouwplan VIII). The development of Malang city is clearly explained by Handinoto (1996) in Figure 1 (a), that the development of Malang city consists of 8 stages. Further research, Subadyo, A. T. (2010) studied about the development stage of the Malang city by determining development of land use zones in the city of Malang, as shown in Figure 1 (b).

Based on the city's historical development, the tracking of IHPS evolution is represented by development in the territory in Figure 1(b), recorded over three time periods (Table 5). The search outcome is then reviewed to see type/characters and functions as IHPS (Table 6). The city development required a renewal/reform of the city structure. However, these days the alteration process is suspected to be having a deleterious effect on the IHPS. The surviving IHPS needs to be evaluated and controlled in order to maintain the urban public spaces' sustainability. 


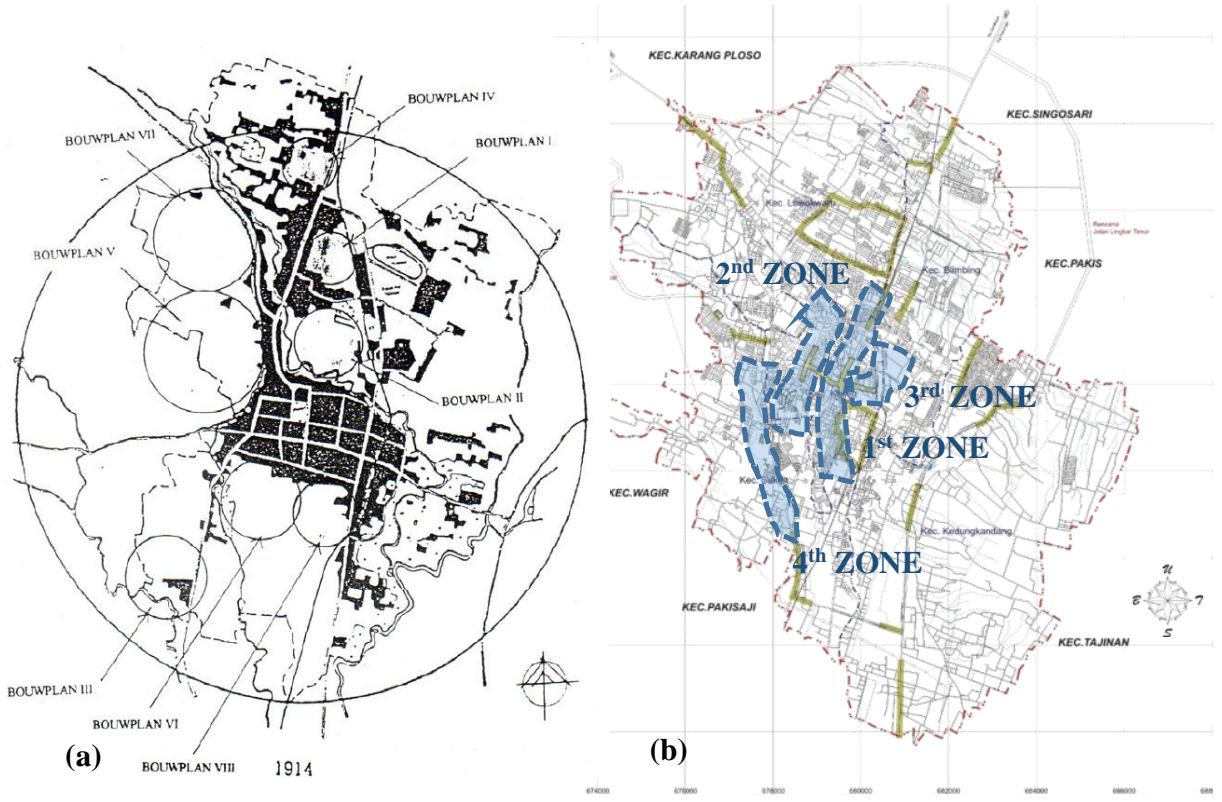

Figure 1. (a) Expansion Points of Malang (Bouwplan I - VIII) Starting from 1917-1935; (b) Research Area of IHPS

Source: (Handinoto, 1996; Subadyo, A. T., 2010)

Table 5. The existence of Malang IHPS based on periodization

\begin{tabular}{|c|c|c|c|c|}
\hline \multirow{2}{*}{ Zone } & \multirow{2}{*}{$\begin{array}{l}\text { Name of IHPS (The } \\
\text { Dutch Naming) }\end{array}$} & \multicolumn{3}{|c|}{ Period of Time } \\
\hline & & 1900-1942 & $1942-1972$ & $1972-2002$ \\
\hline \multirow{7}{*}{$\begin{array}{l}\text { Zone } 1 \\
\text { (Celaket- } \\
\text { Kayutangan- } \\
\text { Alun-Alun) }\end{array}$} & \begin{tabular}{|lr} 
Tumenggung Suryo \\
street (Bengawan Solo \\
straat)
\end{tabular} & Existant & Existant & Existant \\
\hline & $\begin{array}{l}\text { Jaksa Agung Suprapto } \\
\text { street (Tjelaket) }\end{array}$ & Existant & Existant & Existant \\
\hline & $\begin{array}{l}\text { Pattimura street } \\
\text { (Klojen Lorstraat) }\end{array}$ & Existant & Existant & Existant \\
\hline & $\begin{array}{l}\text { Basuki Rahmat street } \\
\text { (Kayoetangan) }\end{array}$ & Existant & Existant & Existant \\
\hline & $\begin{array}{l}\text { Alun-Alun (Aloen- } \\
\text { Aloen) }\end{array}$ & Existant & Existant & Existant \\
\hline & \begin{tabular}{|l|} 
Sartono street/ \\
$\begin{array}{l}\text { Comboran } \\
\text { (Voorschotweg) }\end{array}$ \\
\end{tabular} & Existant & Existant & Existant \\
\hline & $\begin{array}{l}\text { Pasar Besar (Pasarl } \\
\text { Petjinanstraat) }\end{array}$ & Existant & Existant & Existant \\
\hline \multirow{9}{*}{$\begin{array}{l}\text { Zone } 2 \\
\text { (Ijen-Stadion } \\
\text { Gajayana) }\end{array}$} & Mayjen Panjaitan street & Existant & Existant & Existant \\
\hline & $\begin{array}{|lr|}\text { Bandung } & \text { street } \\
\text { (Bandungstraat) } & \\
\end{array}$ & Existant & Existant & Existant \\
\hline & $\begin{array}{|lr|}\begin{array}{l}\text { Jakarta } \\
\text { (Bataviastraat) }\end{array} & \text { street } \\
\end{array}$ & Existant & Existant & Existant \\
\hline & $\begin{array}{l}\text { Malabar Park (Malabar } \\
\text { Urban Forest) }\end{array}$ & Existant & Existant & Existant \\
\hline & Ijen (Ijen Boulevard) & Existant & Existant & Existant \\
\hline & \begin{tabular}{|ll} 
Semeru & street \\
(Smeroestraat/ \\
Smeroeplein)
\end{tabular} & Existant & Existant & Existant \\
\hline & \begin{tabular}{|lr} 
Kawi & street \\
(Kawistraat) & \\
\end{tabular} & Existant & Existant & Existant \\
\hline & Racetrack & Existant & Existant & Not existant \\
\hline & Wilis Park & Existant & Existant & Not xeistant \\
\hline \multirow{2}{*}{$\begin{array}{l}\text { Zone } 3 \\
(\text { Tugu- } \\
\text { Rampal) }\end{array}$} & $\begin{array}{l}\text { Mojopahit street } \\
\text { (Speelmanstraat) }\end{array}$ & Existant & Existant & Existant \\
\hline & \begin{tabular}{|lr} 
Tugul & Alun-Alun \\
Bunder & (Jan \\
Pieterzoencoen plain)
\end{tabular} & Existant & Existant & Existant \\
\hline
\end{tabular}




\begin{tabular}{|c|c|c|c|c|}
\hline \multirow{8}{*}{ Zone } & \multirow{2}{*}{$\begin{array}{l}\text { Name of IHPS (The } \\
\text { Dutch Naming) }\end{array}$} & \multicolumn{3}{|c|}{ Period of Time } \\
\hline & & \multirow{2}{*}{$\begin{array}{c}1900-1942 \\
\text { Existant }\end{array}$} & \multirow{2}{*}{$\begin{array}{c}1942-1972 \\
\text { Existant }\end{array}$} & \multirow{2}{*}{$\frac{1972-2002}{\text { Existant }}$} \\
\hline & \begin{tabular}{|l} 
Kahuripan \\
(Riebeeckstraat
\end{tabular} & & & \\
\hline & $\begin{array}{l}\text { Kertanegara street } \\
\text { (Daendels Boulevard) }\end{array}$ & Existant & Existant & Existant \\
\hline & \begin{tabular}{|lr} 
Ronggowarsito Park \\
(Vander $\quad$ Cappelen \\
straat)
\end{tabular} & Existant & Existant & Existant \\
\hline & $\begin{array}{|ll|}\begin{array}{l}\text { Trunojoyo } \\
\text { (Goedangweg) }\end{array} & \text { street } \\
\end{array}$ & Existant & Existant & Existant \\
\hline & $\begin{array}{|lr|}\text { Panglima } & \text { Sudirman } \\
\text { street } & \text { (Klerekstraat/ } \\
\text { Rampalstraat) }\end{array}$ & Existant & Existant & Existant \\
\hline & Rampal park & Existant & Existant & Existant \\
\hline \multirow{4}{*}{$\begin{array}{l}\text { Zone } 4 \\
\text { (Sukun- } \\
\text { Kasin) }\end{array}$} & \begin{tabular}{|lr}
$\begin{array}{l}\text { Raya } \quad \text { Dieng } \\
\text { (Diengstraat) }\end{array}$ & street \\
\end{tabular} & Existant & Existant & Existant \\
\hline & $\begin{array}{|lr|}\begin{array}{l}\text { Raya } \\
\text { (Langsepstraat) }\end{array} & \\
\end{array}$ & Existant & Existant & Existant \\
\hline & $\begin{array}{ll}\text { APP } & \text { Park/ Ijen } \\
\text { Nirwana } & \end{array}$ & Existant & Existant & $\begin{array}{c}\text { Not existant } \\
\text { (changeover to Ijen } \\
\text { Nirwana Resort) }\end{array}$ \\
\hline & $\begin{array}{l}\text { Sodanco Supriadi street } \\
\text { (Soekoenstraat) }\end{array}$ & Existant & Existant & Existant \\
\hline
\end{tabular}

Table 6. Classification of the type/character and function of IHPS

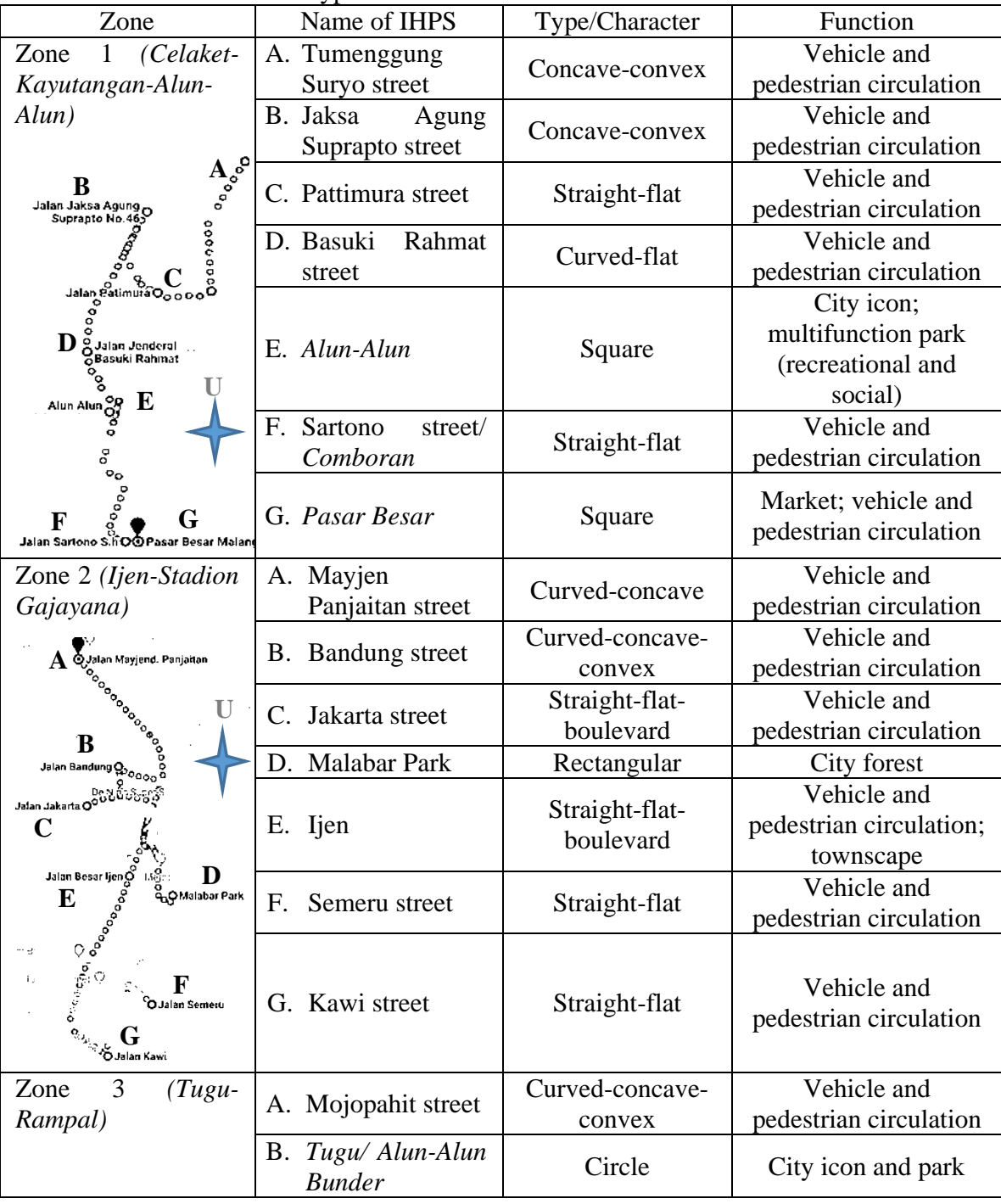




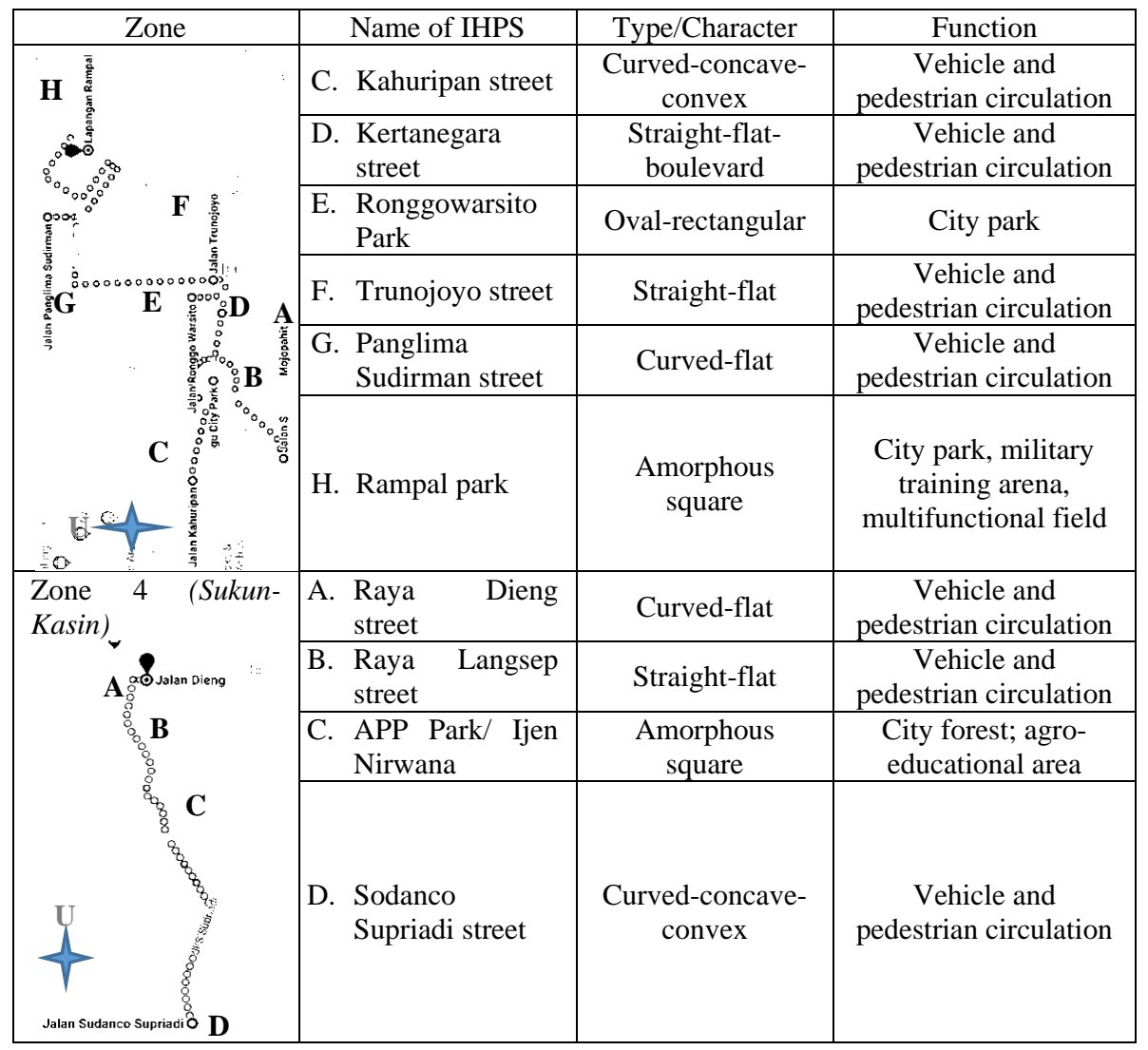

\section{ASSESSMENT OF THE PUBLIC SPACE INTEGRITY AND THE PUBLIC PREFERENCE}

\subsection{Assessment public space integrity}

Based on a composite assessment, the integrity value is classified into three levels (high, moderate and low integrity values). High integrity values are seen dominantly in the Tugu-Rampal area, which reflects the successful IHPS (Table 7.). Ijen Boulevard (39), Alun-alun (38), and Tugu/ Alun-Alun Bunder (38) corridors have the highest integrity rates scattered across zones (Zone 1, 2 and 3). Inclusive public spaces provide an engaging opportunity for various activities, such as relaxation, socialization and education (walking, playing, sitting, chatting or simply resting) (Mehta, 2014) where such activities had occurred in the three IHPS above.

Table 7. The integrity value of Malang IHPS based on historical, aesthetic and functional value

\begin{tabular}{|c|c|c|c|c|c|c|c|c|c|}
\hline \multirow[t]{2}{*}{ Zone } & \multirow{2}{*}{ Name of IHPS } & \multicolumn{2}{|c|}{$\begin{array}{l}\text { Historical } \\
\text { Value }\end{array}$} & \multicolumn{2}{|c|}{$\begin{array}{l}\text { Aesthetic } \\
\text { Value }\end{array}$} & \multicolumn{2}{|c|}{$\begin{array}{l}\text { Functional } \\
\text { Value }\end{array}$} & \multicolumn{2}{|c|}{ Total } \\
\hline & & $\mathrm{V}$ & $\mathrm{C}$ & $\mathrm{V}$ & $\mathrm{C}$ & $\mathrm{V}$ & $\mathrm{C}$ & $\mathrm{V}$ & $\mathrm{C}$ \\
\hline \multirow{6}{*}{$\begin{array}{l}\text { Zone } 1 \\
\text { (Celaket- } \\
\text { Kayutangan- } \\
\text { Alun-Alun) }\end{array}$} & $\begin{array}{l}\text { Tumenggung Suryo } \\
\text { Street }\end{array}$ & 7 & $\mathrm{~L}$ & 7 & M & 11 & $\mathrm{H}$ & 25 & $\mathrm{M}$ \\
\hline & $\begin{array}{l}\text { Jaksa Agung } \\
\text { Suprapto Street }\end{array}$ & 13 & $\mathrm{H}$ & 11 & $\mathrm{H}$ & 12 & $\mathrm{H}$ & 36 & $\mathrm{H}$ \\
\hline & Pattimura Street & 7 & $\mathrm{~L}$ & 7 & $\mathrm{M}$ & 7 & $\mathrm{M}$ & 21 & $\mathrm{~L}$ \\
\hline & Basuki Rahmat Street & 14 & $\mathrm{H}$ & 10 & $\mathrm{H}$ & 11 & $\mathrm{H}$ & 35 & $\mathrm{H}$ \\
\hline & Alun-Alun & 15 & $\mathrm{H}$ & 12 & $\mathrm{H}$ & 11 & $\mathrm{H}$ & 38 & $\mathrm{H}$ \\
\hline & $\begin{array}{l}\text { Sartono Street/ } \\
\text { Comboran }\end{array}$ & 7 & $\mathrm{~L}$ & 6 & $\mathrm{~L}$ & 7 & $\mathrm{M}$ & 20 & $\mathrm{~L}$ \\
\hline
\end{tabular}




\begin{tabular}{|c|c|c|c|c|c|c|c|c|c|}
\hline \multirow[t]{3}{*}{ Zone } & \multirow{2}{*}{ Name of IHPS } & \multicolumn{2}{|c|}{$\begin{array}{l}\text { Historical } \\
\text { Value }\end{array}$} & \multicolumn{2}{|c|}{$\begin{array}{l}\text { Aesthetic } \\
\text { Value }\end{array}$} & \multicolumn{2}{|c|}{$\begin{array}{c}\text { Functional } \\
\text { Value }\end{array}$} & \multicolumn{2}{|c|}{ Total } \\
\hline & & $\mathrm{V}$ & $\mathrm{C}$ & $\mathrm{V}$ & $\mathrm{C}$ & $\mathrm{V}$ & $\mathrm{C}$ & $\mathrm{V}$ & $\mathrm{C}$ \\
\hline & Pasar Besar & 15 & $\mathrm{H}$ & 6 & $\mathrm{~L}$ & 10 & $\mathrm{H}$ & 31 & $\mathrm{H}$ \\
\hline \multirow{9}{*}{$\begin{array}{l}\text { Zone } 2 \\
\text { (Ijen- } \\
\text { Stadion } \\
\text { Gajayana) }\end{array}$} & $\begin{array}{l}\text { Mayjen Panjaitan } \\
\text { Street }\end{array}$ & 7 & $\mathrm{~L}$ & 6 & $\mathrm{~L}$ & 6 & $\mathrm{~L}$ & 19 & $\mathrm{~L}$ \\
\hline & Bandung Street & 12 & $\mathrm{H}$ & 10 & $\mathrm{H}$ & 8 & $\mathrm{M}$ & 30 & $\mathrm{M}$ \\
\hline & Jakarta Street & 13 & $\mathrm{H}$ & 7 & $\mathrm{M}$ & 8 & $\mathrm{M}$ & 28 & $\bar{M}$ \\
\hline & Malabar Park & 12 & $\mathrm{M}$ & 7 & $\mathrm{M}$ & 6 & $\mathrm{~L}$ & 25 & $\mathrm{M}$ \\
\hline & Ijen & 15 & $\mathrm{H}$ & 12 & $\mathrm{H}$ & 12 & $\mathrm{H}$ & 39 & $\mathrm{H}$ \\
\hline & Semeru Street & 14 & $\mathrm{H}$ & 10 & $\mathrm{H}$ & 10 & $\mathrm{M}$ & 34 & $\mathrm{H}$ \\
\hline & Kawi Street & 13 & $\mathrm{H}$ & 10 & $\mathrm{H}$ & 10 & $\mathrm{M}$ & 33 & $\mathrm{H}$ \\
\hline & Racetrack & - & - & - & - & - & - & - & - \\
\hline & Wilis Park & - & - & - & - & - & - & - & - \\
\hline \multirow{8}{*}{$\begin{array}{l}\text { Zone } 3 \\
\text { (Tugu- } \\
\text { Rampal) }\end{array}$} & Mojopahit Street & 14 & $\mathrm{H}$ & 8 & $\mathrm{M}$ & 9 & $\mathrm{M}$ & 31 & $\mathrm{H}$ \\
\hline & $\begin{array}{l}\text { Tugul Alun-Alun } \\
\text { Bunder }\end{array}$ & 15 & $\mathrm{H}$ & 12 & $\mathrm{H}$ & 11 & $\mathrm{H}$ & 38 & $\mathrm{H}$ \\
\hline & Kahuripan Street & 10 & $\mathrm{M}$ & 7 & $\mathrm{M}$ & 7 & $\mathrm{M}$ & 24 & $\bar{M}$ \\
\hline & Kertanegara Street & 14 & $\mathrm{H}$ & 12 & $\mathrm{H}$ & 11 & $\mathrm{H}$ & 37 & $\mathrm{H}$ \\
\hline & Ronggowarsito Park & 12 & $\mathrm{M}$ & 10 & $\mathrm{H}$ & 10 & $\mathrm{H}$ & 32 & $\mathrm{H}$ \\
\hline & Trunojoyo Street & 11 & $\mathrm{M}$ & 8 & $\mathrm{M}$ & 10 & $\mathrm{H}$ & 29 & $\bar{M}$ \\
\hline & $\begin{array}{l}\text { Panglima Sudirman } \\
\text { Street }\end{array}$ & 12 & $\mathrm{M}$ & 10 & $\mathrm{H}$ & 11 & $\mathrm{H}$ & 33 & $\mathrm{H}$ \\
\hline & Rampal Park & 13 & $\mathrm{H}$ & 10 & $\mathrm{H}$ & 11 & $\mathrm{H}$ & 34 & $\mathrm{H}$ \\
\hline \multirow{4}{*}{$\begin{array}{l}\text { Zone } 4 \\
\text { (Sukun- } \\
\text { Kasin) }\end{array}$} & Raya Dieng Street & 12 & $\mathrm{M}$ & 9 & $\mathrm{M}$ & 8 & $\mathrm{M}$ & 27 & $\mathrm{M}$ \\
\hline & Raya Langsep Street & 10 & $\mathrm{M}$ & 8 & $\mathrm{M}$ & 9 & $\mathrm{M}$ & 27 & $\mathrm{M}$ \\
\hline & $\begin{array}{l}\text { APP Park/ Ijen } \\
\text { Nirwana }\end{array}$ & - & - & - & - & - & - & - & - \\
\hline & $\begin{array}{ll}\text { Sodanco } & \text { Supriadi } \\
\text { Street } & \end{array}$ & 7 & M & 7 & M & 8 & M & 22 & M \\
\hline
\end{tabular}

$\mathrm{V}=$ value, $\mathrm{C}=$ category of value $(\mathrm{H}=$ high, if $\mathrm{V}=31-39 ; \mathrm{M}=$ moderate, if $\mathrm{V}=22-30 ; \mathrm{L}=$ low, if $\mathrm{V}=13-21$ )

$=$ the highest value

As a remainder from a past era, the inclusive public space maintains yet a high representation of its original historical character. Square and circle patterns (in Alun-alun and Tugu/ Alun-Alun Bunder), townscape corridor (Ijen Boulevard) and historical buildings (Alun-alun: Tax Office, Bank Indonesia Office, State Treasury Office, Pelangi Hotel, Jami' Mosque, and GPIB Immanuel Church; Tugu/ Alun-alun Bunder: Malang City Hall, Complex of State Senior High School 1, 3, and 4, Skodam Hall V Brawijaya, Tugu Malang Hotel, and Splendid Inn; Ijen Boulevard: the housing of the Dutch upper class along the two sides of the street corridor) are the most dominant of the historical aspects of the colonial city design. The space proportion and scale strongly support its aesthetic value. As IHPS, those public spaces are sufficient to provide comfortable use and have been utilized optimally by the community. However, it also needs to be considered that congestion of activity, particularly in public spaces close to intersections, remains problematic (Sedyowati, Suhartanto, \& Sholichin, 2018).

The alun-alun has an important meaning to cities on Java Island and represents the concept of the urban-hub - the "palace center" idea - based on the high philosophical principles of Hastabrata. It has become the center of community activity and, for Malang, an icon and landmark. 


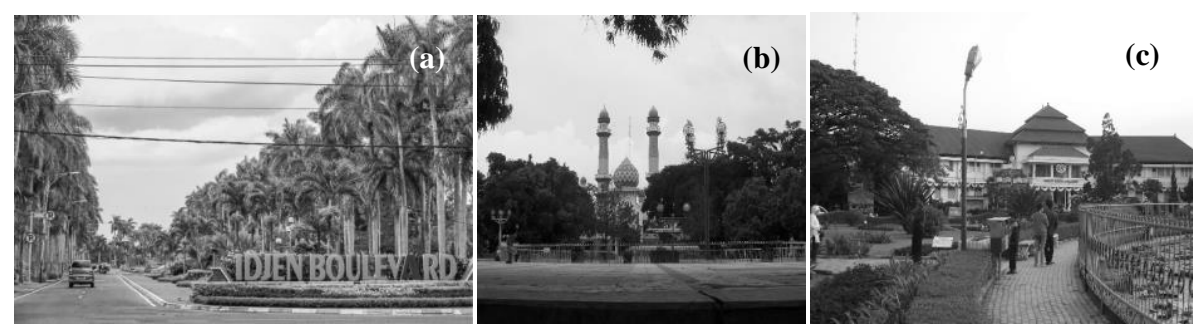

Figure 2. The IHPS of highest integrity value (a) Idjen Boulevard; (b) Alun-Alun; (c) Tugu/ Alun-alun Bunder

In addition, Ijen - Gajayana Stadium zone has the highest integrity values among Kawi Street, Semeru Street, Gajayana Stadium open space, Bandung Street and Ijen Boulevard. While, Jakarta Street, Bandung Street, and Malabar City Forest have a moderate value, although the value and historical significance of the Jakarta Street corridor is high, in fact, it has undergone many changes, thus lowering its aesthetic value. Furthermore, a low integrity value is shown in Mayjen Panjaitan Street, which has experienced many changes in all areas of value.

Moderate integrity values in Tugu-Rampal are shown on Kahuripan and Trunojoyo streets, even though there are meaningful historic public buildings such as the Senaputra Amusement Park (Kahuripan Street) and Kota Baru Railway Station (Trunojoyo Street). In the Sukun - Kasin zone, all IHPS (Sodanco Supriadi, Langsep and Raya Dieng streets) have moderate space integrity values.

High integrity value IHPS refers to public space which has a high value of historical character, image (inclusivity) and aesthetics in each region. On the other hand, areas of moderate and low IHPS value fulfill less of those three criteria of the IHPS integrity value. Further analysis explains more about the relationship between public space integrity within the area of community preference.

\subsection{Public Preference of IHPS}

In general, the function of inclusive public spaces should fulfill criteria of being responsive, democratic and meaningful (Carr et al., 1992). Firstly, the "responsive" requirement means that inclusive public space is used for a wide range of activities and interests. Secondly, for the "democratic" requirement, inclusive public space can be used by people from various social, economic and cultural backgrounds, and also is accessible by everyone. Lastly, the "meaningful" requirement means that inclusive public space establishes an important relationship between humans and space as a social context ( $\underline{\text { Carr et }}$ al., 1992).

According to Carmona et al. (2010), the success of an inclusive public space can be measured by (1) Amenities and Images, (2) Access and Linkage, (3) Economic Usefulness, and (4) Social Needs variables. Inclusive public space utilization needs to consider peoples' expressed preferences in an effort to meet those required variable parameters. To maintain sustainability, the development of such areas should involve its occupants and user societies (Budihardjo \& Sujarto, 1999; Turcu, 2013). Those local communities are not only used as an object of historic area development, but also should be involved as a subject in giving suggestions and thoughts on planning, implementation and supervision. 
Table 9. Public preference level of Zone 2 (Ijen - Gajayana Stadium)

\begin{tabular}{|c|c|c|c|c|c|c|c|}
\hline \multirow{2}{*}{ Variable } & \multirow{2}{*}{ Operational Variable } & \multicolumn{6}{|c|}{ The Number of Respondent Needs $(\%)^{*}$} \\
\hline & & VH & $\mathrm{H}$ & $\mathrm{M}$ & $\mathrm{L}$ & VL & Total \\
\hline \multirow{4}{*}{$\begin{array}{l}\text { Amenities } \\
\text { and Images }\end{array}$} & Physical character & 43 & 27 & 20 & 7 & 3 & 100 \\
\hline & Pedestrian ways & 33 & 30 & 30 & 7 & 0 & 100 \\
\hline & Street furniture & 50 & 23 & 13 & 13 & 0 & 100 \\
\hline & Vegetation barriers & 40 & 30 & 17 & 10 & 3 & 100 \\
\hline \multirow{4}{*}{$\begin{array}{l}\text { Access and } \\
\text { Linkage }\end{array}$} & Minibus availability & 30 & 40 & 30 & 0 & 0 & 100 \\
\hline & Pedestrian way linkage & 50 & 30 & 17 & 3 & 0 & 100 \\
\hline & Halte & 0 & 3 & 50 & 17 & 30 & 100 \\
\hline & Car parks & 67 & 20 & 10 & 3 & 0 & 100 \\
\hline \multirow{4}{*}{$\begin{array}{l}\text { Economic } \\
\text { Usefulness }\end{array}$} & Coordinating of street traders & 7 & 47 & 17 & 27 & 23 & 100 \\
\hline & Investors & 3 & 20 & 17 & 43 & 17 & 100 \\
\hline & Company types & 0 & 10 & 30 & 50 & 10 & 100 \\
\hline & Commercial purpose & 0 & 50 & 10 & 23 & 17 & 100 \\
\hline \multirow{4}{*}{ Social Needs } & $\begin{array}{l}\text { Type and frequency of } \\
\text { activity }\end{array}$ & 23 & 53 & 7 & 17 & 0 & 100 \\
\hline & Extra hours of activity & 30 & 30 & 13 & 10 & 17 & 100 \\
\hline & Facilities for various ages & 40 & 27 & 10 & 17 & 7 & 100 \\
\hline & Support facilities & 7 & 0 & 37 & 33 & 23 & 100 \\
\hline
\end{tabular}

*VH = very high (very important); $\mathrm{H}=$ high (important); $\mathrm{M}=$ moderate (quite important); $\mathrm{L}$ $=$ low (less important); $\mathrm{VL}=$ very low (not important)

$=>50 \%$ respondent $\quad \square=$ the highest percentages

In the third table (Table 10), the operational variables that show a high level of importance (very important $(\mathrm{VH})$ and important $(\mathrm{H})$ ) are: physical character enhancements (80\%), availability of pedestrian ways (73\%), street furniture availability (73\%), vegetation barriers (73\%), minibus availability $(70 \%)$, pedestrian way linkage $(80 \%)$, car parks $(84 \%)$, coordinating of street traders (54\%), increasing of activity type and frequency (76\%), extra hours of public activity (73\%) and facilities for various ages (67\%). The respondent answers recognised the Amenities and Images, Access and Linkage and Social Needs variables as the main necessity in Zone 3.

Table 10. Public preference level of Zone 3 (Tugu-Rampal)

\begin{tabular}{|c|c|c|c|c|c|c|c|}
\hline \multirow{2}{*}{ Variable } & \multirow{2}{*}{ Operational Variable } & \multicolumn{6}{|c|}{ The Number of Respondent Needs $(\%)^{*}$} \\
\hline & & $\mathrm{VH}$ & $\mathrm{H}$ & $\mathrm{M}$ & $\mathrm{L}$ & VL & Total \\
\hline \multirow{4}{*}{$\begin{array}{l}\text { Amenities } \\
\text { and Images }\end{array}$} & Physical character & 53 & 27 & 17 & 3 & 0 & 100 \\
\hline & Pedestrian ways & 43 & 30 & 20 & 7 & 0 & 100 \\
\hline & Street furniture & 23 & 50 & 13 & 13 & 0 & 100 \\
\hline & Vegetation barriers & 40 & 33 & 17 & 10 & 0 & 100 \\
\hline \multirow{4}{*}{$\begin{array}{l}\text { Access and } \\
\text { Linkage }\end{array}$} & Minibus availability & 30 & 40 & 30 & 0 & 0 & 100 \\
\hline & Pedestrian way linkage & 50 & 30 & 10 & 3 & 7 & 100 \\
\hline & Halte & 0 & 3 & 50 & 30 & 17 & 100 \\
\hline & Car parks & 17 & 67 & 10 & 7 & 0 & 100 \\
\hline \multirow{4}{*}{$\begin{array}{l}\text { Economic } \\
\text { Usefulness }\end{array}$} & Coordinating of street traders & 27 & 27 & 23 & 17 & 7 & 100 \\
\hline & Investors & 3 & 20 & 17 & 43 & 17 & 100 \\
\hline & Company types & 0 & 10 & 30 & 50 & 10 & 100 \\
\hline & Commercial purpose & 0 & 10 & 50 & 23 & 17 & 100 \\
\hline \multirow{4}{*}{ Social Needs } & $\begin{array}{l}\text { Type and frequency of } \\
\text { activity }\end{array}$ & 53 & 23 & 7 & 17 & 0 & 100 \\
\hline & Extra hours of activity & 43 & 30 & 30 & 10 & 0 & 100 \\
\hline & Facilities for various ages & 40 & 27 & 10 & 17 & 7 & 100 \\
\hline & Support facilities & 7 & 0 & 37 & 33 & 23 & 100 \\
\hline
\end{tabular}

*VH = very high (very important); $\mathrm{H}=$ high (important); $\mathrm{M}=$ moderate (quite important); $\mathrm{L}$ $=$ low (less important); $\mathrm{VL}=$ very low (not important)

$\square=>50 \%$ respondent $\quad \square=$ the highest percentages

In the fourth table (Table 11), the operational variables that are considered very important $(\mathrm{VH})$ and important $(\mathrm{H})$ by most respondents (more than 50\%) are: physical character enhancements $(60 \%)$, availability of pedestrian ways $(63 \%)$, street furniture availability $(73 \%)$, vegetation barriers $(60 \%)$, minibus availability $(70 \%)$, pedestrian way linkage $(80 \%)$, car parks $(68 \%)$, investors 
(60\%), commercial purpose (90\%) and increasing of activity type and frequency $(76 \%)$. From those 16 variable operational questions, the fundamental needs were shown in Zone 4 to be Amenities and Images, as well as Access and Linkage. The availability of pedestrian and minibus ways is a necessity in establishing inter-regional linkages. The existence of a street market, as well as increasing the type and frequency of activities is intended to be an optimal use of IHPS.

Table 11. Public preference level of Zone 4 (Sukun - Kasin)

\begin{tabular}{|c|c|c|c|c|c|c|c|}
\hline \multirow{2}{*}{ Variable } & \multirow{2}{*}{ Operational Variable } & \multicolumn{6}{|c|}{ The Number of Respondent Needs (\%)* } \\
\hline & & VH & $\mathrm{H}$ & $\mathrm{M}$ & $\mathrm{L}$ & VL & Total \\
\hline \multirow{4}{*}{$\begin{array}{l}\text { Amenities } \\
\text { and Images }\end{array}$} & Physical character & 20 & 40 & 7 & 20 & 13 & 100 \\
\hline & Pedestrian ways & 33 & 30 & 30 & 7 & 0 & 100 \\
\hline & Street furniture & 23 & 50 & 13 & 13 & 0 & 100 \\
\hline & Vegetation barriers & 20 & 40 & 17 & 10 & 13 & 100 \\
\hline \multirow{4}{*}{$\begin{array}{l}\text { Access and } \\
\text { Linkage }\end{array}$} & Minibus availability & 40 & 30 & 20 & 10 & 0 & 100 \\
\hline & Pedestrian way linkage & 50 & 30 & 10 & 3 & 7 & 100 \\
\hline & Halte & 10 & 17 & 23 & 20 & 30 & 100 \\
\hline & Car parks & 21 & 47 & 20 & 7 & 7 & 100 \\
\hline \multirow{4}{*}{$\begin{array}{l}\text { Economic } \\
\text { Usefulness }\end{array}$} & Coordinating of street traders & 13 & 17 & 13 & 37 & 20 & 100 \\
\hline & Investors & 27 & 33 & 33 & 3 & 3 & 100 \\
\hline & Company types & 7 & 3 & 20 & 33 & 37 & 100 \\
\hline & Commercial purpose & 23 & 67 & 3 & 7 & 0 & 100 \\
\hline \multirow{4}{*}{ Social Needs } & $\begin{array}{l}\text { Type and frequency of } \\
\text { activity }\end{array}$ & 53 & 23 & 7 & 17 & 0 & 100 \\
\hline & Extra hours of activity & 20 & 13 & 23 & 30 & 13 & 100 \\
\hline & Facilities for various ages & 13 & 10 & 17 & 20 & 40 & 100 \\
\hline & Support facilities & 17 & 13 & 10 & 33 & 27 & 100 \\
\hline
\end{tabular}

*VH = very high (very important); $\mathrm{H}=$ high (important); $\mathrm{M}=$ moderate (quite important); $\mathrm{L}$ $=$ low (less important); $\mathrm{VL}=$ very low (not important)

$\square=>50 \%$ respondent $\quad \square=$ the highest percentages $(\geq 70 \%)$

Generally, all operational variables of the Amenities and Images (physical character enhancement, the availability of pedestrian ways, street furniture availability, and the existence of barrier vegetation) is selected by the majority of respondents in all four IHPS zones. Meanwhile, the Access and Linkage becomes the second needs variable in all IHPS zones. Nevertheless, the highest percentage of necessity is shown to be the operational variables of the Access and Linkage variable (the need for pedestrian way linkage of $80 \%$ in Zone 1, car parks in Zone 2 (87\%) and Zone 3 (84\%)). Interestingly, the highest public demand selected in Zone 4 (Sukun - Kasin) is for commercial purpose (90\%) in the Economic Usefulness variable.

Table 12. Top priorities in improving community needs on the low-moderate integrity level of IHPS

\begin{tabular}{|c|c|c|c|c|}
\hline Zone & $\begin{array}{c}\text { Name of } \\
\text { IHPS (level } \\
\text { of integrity*) }\end{array}$ & $\begin{array}{l}\text { Type/ } \\
\text { character }\end{array}$ & Function & $\begin{array}{l}\text { Top Priorities in Improving } \\
\text { Community Needs }\end{array}$ \\
\hline \multirow{3}{*}{$\begin{array}{l}\text { Zone } 1 \\
\text { (Celaket- } \\
\text { Kayutangan- } \\
\text { Alun-Alun) }\end{array}$} & $\begin{array}{c}\text { Tumenggung } \\
\text { Suryo Street } \\
\text { (M) }\end{array}$ & $\begin{array}{l}\text { Concave- } \\
\text { convex }\end{array}$ & \multirow{3}{*}{$\begin{array}{l}\text { Vehicle } \\
\text { and } \\
\text { pedestrian } \\
\text { circulation }\end{array}$} & \multirow{3}{*}{$\begin{array}{l}\text { 1. Pedestrian way linkage } \\
\text { 2. Car park s } \\
\text { 3. Activity type and } \\
\text { frequency } \\
\text { 4. Street furniture availability } \\
\text { 5. Commercial purpose } \\
\text { 6. Minibus availability }\end{array}$} \\
\hline & $\begin{array}{l}\text { Pattimura } \\
\text { Street (L) }\end{array}$ & Straight-flat & & \\
\hline & $\begin{array}{c}\text { Sartono } \\
\text { Street/ } \\
\text { Comboran } \\
\text { (L) }\end{array}$ & Straight-flat & & \\
\hline Zone 2 & $\begin{array}{l}\text { Mayjen } \\
\text { Panjaitan } \\
\text { Street (L) }\end{array}$ & $\begin{array}{l}\text { Curved- } \\
\text { concave }\end{array}$ & $\begin{array}{l}\text { Vehicle } \\
\text { and }\end{array}$ & $\begin{array}{l}\text { 1. Car parks } \\
\text { 2. Pedestrian way linkage }\end{array}$ \\
\hline
\end{tabular}




\begin{tabular}{|c|c|c|c|c|}
\hline Zone & $\begin{array}{c}\text { Name of } \\
\text { IHPS (level } \\
\text { of integrity*) }\end{array}$ & $\begin{array}{l}\text { Type/ } \\
\text { character }\end{array}$ & Function & $\begin{array}{l}\text { Top Priorities in Improving } \\
\text { Community Needs }\end{array}$ \\
\hline \multirow[t]{3}{*}{$\begin{array}{l}\text { (Ijen- } \\
\text { Stadion } \\
\text { Gajayana) }\end{array}$} & $\begin{array}{l}\text { Bandung } \\
\text { Street (M) }\end{array}$ & $\begin{array}{l}\text { Curved- } \\
\text { concave- } \\
\text { convex }\end{array}$ & \multirow[t]{2}{*}{$\begin{array}{l}\text { pedestrian } \\
\text { circulation }\end{array}$} & \multirow{3}{*}{$\begin{array}{l}\text { 3. Activity type and } \\
\text { frequency } \\
\text { 4. Street furniture availability } \\
\text { 5. Physical character } \\
\text { 6. Vegetation barriers } \\
\text { 7. Minibus availability }\end{array}$} \\
\hline & $\begin{array}{c}\text { Jakarta } \\
\text { Street }(\mathrm{M})\end{array}$ & $\begin{array}{l}\text { Straight- } \\
\text { flat- } \\
\text { boulevard }\end{array}$ & & \\
\hline & $\begin{array}{l}\text { Malabar } \\
\text { Park (M) }\end{array}$ & Rectangular & City forest & \\
\hline \multirow[t]{2}{*}{$\begin{array}{l}\text { Zone } 3 \\
\text { (Tugu- } \\
\text { Rampal) }\end{array}$} & $\begin{array}{l}\text { Kahuripan } \\
\text { Street (M) }\end{array}$ & $\begin{array}{c}\text { Curved- } \\
\text { concave- } \\
\text { convex } \\
\end{array}$ & \multirow[b]{2}{*}{$\begin{array}{l}\text { Vehicle } \\
\text { and } \\
\text { pedestrian } \\
\text { circulation }\end{array}$} & \multirow{2}{*}{$\begin{array}{l}\text { 1. Car parks } \\
\text { 2. Physical character } \\
\text { 3. Pedestrian way linkage } \\
\text { 4. Activity type and } \\
\text { frequency } \\
\text { 5. Pedestrian way availability } \\
\text { 6. Street furniture availability } \\
\text { 7. Vegetation barriers } \\
\text { 8. Extra hours of public } \\
\text { activity } \\
\text { 9. Minibus availability } \\
\end{array}$} \\
\hline & $\begin{array}{l}\text { Trunojoyo } \\
\text { Street (M) }\end{array}$ & Straight-flat & & \\
\hline \multirow{3}{*}{$\begin{array}{l}\text { Zone } 4 \\
\text { (Sukun- } \\
\text { Kasin) }\end{array}$} & $\begin{array}{l}\text { Raya Dieng } \\
\text { Street (M) }\end{array}$ & Curved-flat & \multirow{3}{*}{$\begin{array}{l}\text { Vehicle } \\
\text { and } \\
\text { pedestrian } \\
\text { circulation }\end{array}$} & \multirow{3}{*}{$\begin{array}{l}\text { 1. Commercial purpose } \\
\text { 2. Pedestrian way linkage } \\
\text { 3. Activity type and frequency } \\
\text { 4. Street furniture availability } \\
\text { 5. Minibus availability }\end{array}$} \\
\hline & $\begin{array}{c}\text { Raya } \\
\text { Langsep } \\
\text { Street }(\mathrm{M})\end{array}$ & Straight-flat & & \\
\hline & $\begin{array}{c}\text { Sodanco } \\
\text { Supriadi } \\
\text { Street (M) }\end{array}$ & $\begin{array}{l}\text { Curved- } \\
\text { concave- } \\
\text { convex }\end{array}$ & & \\
\hline
\end{tabular}

*M = Moderate, L= Low; based on Table 7.

The public preference assessment is a manifestation of public awareness in maintaining the environmental sustainability value, especially in IHPS, that has an integrity value focused on history, aesthetics and function. Maximizing the potentiality of regional conservation based on community preferences can enhance the low to moderate integrity values derived from the results of the IHPS integrity assessment. The focus on primary needs enhancement is obtained from $\geq 70 \%$ respondents and the top priorities are shown in sequence on Table 12. The majority of low to moderate integrity IHPS is in areas of functionality, such as pedestrian corridors and for vehicle access, while its physical characters tend to be linear line variations.

\section{CONCLUSION}

From the assessment analysis of Malang IHPS, it is concluded that actions related to increasing the integrity level should be consistent with the following: (1) High integrity of IHPS: protecting the historical character from various negative changes (including limiting the addition of functions); (2) Moderate integrity of IHPS: adaptive use effort (utilizing, replicating, recreating (reconstructing)) in order to strengthen the existing character; (3) Low integrity of IHPS: optimal renewal effort (in the physical order and function, but also continued supporting of the regional image).

In the future, the development of Malang as a city of destination requires a vigorous public space to be visited by the wider community inclusive of different socio-economic levels. This ideal can be realized if the planning is done comprehensively, holistically and in an integrated fashion. Conservation efforts should take into consideration all regional requirements related to a wide range of issues. These activities should focus on more creative utilization 
efforts, should produce new heritage products, lead to implementation of participation programs, as well as economic and socio-cultural activities in those conservation areas, which are wholly supported by public preference.

Based on that, further analysis of regulatory products is required in subsequent research. Such study would aim to assess the effectiveness of regulatory implementation and the extent of government support in trying to preserve and utilize historic areas, especially in IHPS in Malang. Then, the final synthesis will combine previous analysis into formulation of a concept for utilization of the IHPS as the basis for preserving and developing historic areas in Malang.

\section{ACKNOWLEDGMENT}

Many thanks to DIKTI of Republic of Indonesia, which has supported funding during this fundamental research, and thanks also to others who helped improve the writing of this manuscript.

\section{REFERENCES}

Abdel-Rahman, N. H. (2016). "Establishing a Process for Handling Valuable Landscapes: A Comparative Analysis for Managing Historical Parks in Egypt". Procedia-Social and Behavioral Sciences, 225, 376-390.

Alamoush, S. J., Ja'afar, N. H., Husini, E. M., \& Ismail, W. N. W. (2017). "Comfort Character for Traditional Street Users, a Case Study of Rainbow Street, Amman". Proceedings of International Conference on Advanced Technology, Kuala Lumpur, pp. 10-13.

Arifin, H. S., Arifin, N. H. S., \& Suryadarma, I. (2002). "Integrating the Value of Local Tradition and Culture in Ecological Landscape Planning in Indonesia". Landscape Research-Journal of the Japanese Institute of Landscape Architecture, 65, 196-200.

Australia ICOMOS Incorporated. (2000). The Burra Charter: The Australia Icomos Charter for Places of Cultural Significance (1999) with Associated Guidelines and Code on the Ethics of Coexistence. Burwood: Australia ICOMOS Incorporated.

Australia ICOMOS Incorporated. (2013). The Burra Charter: The Australia Icomos Charter for Places of Cultural Significance, 2013. Burwood: Australia ICOMOS Incorporated.

Bandarin, F., \& van Oers, R. (Eds.). (2015). Reconnecting the City: The Historic Urban Landscape Approach and the Future of Urban Heritage. West Sussex: John Wiley \& Sons.

Baskoro, S. (2017). "Surabaya Sebagai Kota Kolonial Modern Pada Akhir Abad Ke-19: Industri, Transportasi, Permukiman, Dan Kemajemukan Masyarakat (Surabaya as Modern Colonial City at the End of 19th Century: Industry, Transportation, Settlement, and Pluralism Society)". Mozaik Humaniora, 17(1), 157-180.

Basundoro, P. (2015). "The Two Alun-Alun of Malang (1930-1960)". In Freek Colombijn \& Coté, J. (Eds.), Cars, Conduits, and Kampongs: The Modernization of the Indonesian City, 1920-1960 (pp. 272-299). Leiden: Brill. doi: http://doi.org/10.1163/9789004280724_012.

Budihardjo, E., \& Sujarto, D. (1999). Kota Berkelanjutan (Sustainable City). Bandung: Alumni.

Carmona, M. (2015). "Re-Theorising Contemporary Public Space: A New Narrative and a New Normative". Journal of Urbanism: International Research on Placemaking and Urban Sustainability, 8(4), 373-405.

Carmona, M., Tiesdell, S., Heath, T., \& Oc, T. (2010). Public Places - Urban Spaces: The Dimensions of Urban Design. (2nd ed.). Oxford: Architectural Press.

Carr, S., Francis, M., Rivlin, L. G., \& Stone, A. M. (1992). Public Space. Cambridge: Cambridge University Press.

Catanese, A. J., \& Snyder, J. C. (1988). Planejamento Urbano (Urban Planning). New York: McGraw-Hill College.

Handinoto. (1996). "Perkembangan Kota Malang Pada Jaman Kolonial (1914-1940) (the Development of Malang City in the Colonial Period (1914-1940))". DIMENSI, 22, 1-29.

Hardoy, J. E., \& Satterthwaite, D. (2014). Squatter Citizen: Life in the Urban Third World. New York: Earthscan. 
Harun, N. Z., Mansor, M., \& Said, I. (2015). "Place Rootedness Suggesting the Loss and Survival of Historical Public Spaces". Procedia Environmental Sciences, 28, 528-537.

Helly, L., \& Budiarti, R. (2005). "Cultural Significance Valuation (Case Study: Corridor of Cut Mutia Street-Suropati Park, Menteng Jakarta)". Proceedings of International Seminar on Modern Urban and Architectural Heritage, Jakarta: Architecture Department, Faculty of Civil Engineering and Planning, Trisakti University.

Jacobs, A. B. (1993). Great Streets. Cambridge: The MIT Press.

Jalaladdini, S., \& Oktay, D. (2013). "Interrogating Vitality of the Streets in Two Cypriot Towns". Asian Journal of Environment-Behaviour Studies, 4(11), 63-73.

Kaymaz, I. (2013). "Urban Landscapes and Identity". In Özyavuz, M. (Ed.), Advances in Landscape Architecture: IntechOpen.

Kostof, S., \& Castillo, G. (1992). The City Assembled: The Elements of Urban Form through History. (Reprint Ed.). London: Thames and Hudson.

Mehta, V. (2014). "Evaluating Public Space". Journal of Urban Design, 19(1), 53-88.

Nasution, A. D., \& Zahrah, W. (2012). "Public Open Space Privatization and Quality of Life, Case Study Merdeka Square Medan". Procedia-Social and Behavioral Sciences, 36, 466475.

Ridjal, A. M., Antariksa, A., Suryasari, N., \& Santoso, J. T. (2016). "Building Form Berdasarkan Sejarah Kawasan Bangunan Pada Jalan Basuki Rahmat Malang (Building Form Based on the History of Building Area on Jalan Basuki Rahmat Malang)". Jurnal RUAS (Review of Urbanism and Architectural Studies), 14(2), 34-46.

Ritchie, J., Lewis, J., Nicholls, C. M., \& Ormston, R. (2013). Qualitative Research Practice: A Guide for Social Science Students and Researchers. London: SAGE.

Romice, O., Thwaites, K., Porta, S., Greaves, M., Barbour, G., \& Pasino, P. (2017). "Urban Design and Quality of Life". In Fleury-Bahi, G., Pol, E., \& Navarro, O. (Eds.), Handbook of Environmental Psychology and Quality of Life Research. International Handbooks of Quality-of-Life. Cham: Springer.

Santoso, J. T., Suryasari, N., \& Antariksa, A. (2013). "Tradisionalisme Dalam Arsitektur Kolonial Belanda Di Kota Malang ((Traditionalism in Dutch Colonial Architecture in Malang City)". Jurnal RUAS (Review of Urbanism and Architectural Studies), 11(2), 37-50.

Sedyowati, L., Suhartanto, E., \& Sholichin, M. (2018). "Runoff Behavior on Urban Road Intersection Based on Flow Profile Simulation". International Review for Spatial Planning and Sustainable Development, 6(1), 32-44.

Srichuae, S., Nitivattananon, V., \& Perera, R. (2016). "Aging Society in Bangkok and the Factors Affecting Mobility of Elderly in Urban Public Spaces and Transportation Facilities". Iatss Research, 40(1), 26-34.

Subadyo, A. T. (2010). Analisis Ruang Publik Inklusif Bersejarah Sebagai Dasar Pelestarian Kawasan Bersejarah Di Kota Malang (Analysis of the Historic Inclusive Public Space as the Foundation for Preservation of Historic Area in Malang City). Jakarta, Indonesia: Laporan Penelitian Fundamental DP2M Dikti.

Subadyo, A. T., \& Poerwoningsih, D. (2017). "Design of Integrated Infrastructure Development in Poncokusumo Agropolitan Region-Malang, Indonesia". Ecology, Environment and Conservation, 23(1), 63-70.

Sunaryo, R. G., Soewarno, N., Ikaputra, I., \& Setiawan, B. (2013). "Colonial and Traditional Urban Space in Java: A Morphological Study of Ten Cities". DIMENSI (Journal of Architecture and Built Environment), 40(2), 77-88.

Turcu, C. (2013). "Re-Thinking Sustainability Indicators: Local Perspectives of Urban Sustainability". Journal of Environmental Planning and Management, 56(5), 695-719.

Tutuko, P., \& Shen, Z. (2016). "The Effect of Land Use Zonings on Housing Development: The Introduction of Cdl Approach in the Border Area of Surabaya and Sidoarjo Regency, Indonesia". Procedia-Social and Behavioral Sciences, 227, 107-114.

Yoshii, Y. (2016). "Preserving Alleyways to Increase Walkability of Historical Japanese Cities". Procedia-Social and Behavioral Sciences, 216, 603-609. 